\title{
Evaluation of the post-labioplasty result according to the comprehensive assessment performed by Indonesian Cleft Center team
}

\author{
Siti Nur Nabihah Binti Zainul Abidin, ${ }^{*}$ Ida Ayu Astuti, ${ }^{*}$ Asri Arumsari, ${ }^{*}$ \\ *Department of Dental Surgery Faculty of Dentistry Universitas Padjadjaran
}

\begin{abstract}
Introduction: Labioplasty is a surgical approach to reconstructs and repairs the cleft lip defect. The main purpose of this study is to observe the performance result of labioplasty through out the period of January till December 2007 according to the comprehensive assessment performed by Indonesian Cleft Center Team. Other purpose is to determine the least and the most complicated structure to be reconstructed in labioplasty. Apart from that, types of secondary reconstructive surgery, how many patients require and implement this secondary surgery are determined in this study. Methods: The method used for this study was descriptive retrospective which in the sample are post-labioplasty patients that came for assessment. With astounding years of experience, Indonesian Cleft Center Team is expected able to handle every case judiciously regarding its clinical severity. Results: Result shows that the performance result of labioplasty does not necessarily coincided with the severity of the cases. The most complicated structure to be reconstructed in labioplasty is Cupid's bow whilst the least complicated are the thickness of vermilion and avoidance to create cicatrix. Conclusion: Type of secondary reconstructive indicated for the patient to repair the remaining deformities are secondary lip repair, rhinoplasty, fistula closure and bone graft. The amount of patient that is indicated for it is in total 25 patients and only 1 patient implemented the surgery.
\end{abstract}

Keywords: Cleft lip, Performance of Labioplasty, The Comprehensive Assessment

\section{INTRODUCTION}

In the age of empiricism, many congenital deformities including cleft lip and cleft palate were evidence of the presence of an evil spirit in the afflicted child. These children were then often removed from the tribe and left to die in the surrounding wilderness. ${ }^{1}$ Cleft patient's initial appearance may be grotesque. This is because the deformities can be seen, felt and heard, and constitutes a serious affliction to those who have them. ${ }^{2}$

Cleft is a congenital abnormal space or gap in the upper lip, alveolus, or palate. Cleft lip and cleft palate are the most common serious congenital anomalies to affect the orofacial region. ${ }^{2}$ The main pathophysiology of this defect is the failure of fusion of the maxillary and medial nasal processes produces the common congenital malformation of the cleft lip, which may be unilateral or bilateral. ${ }^{3}$ while cleft palate generally are because of malformation in palatogenesis.

The incidence of cleft lip is about 1 per 1000 live birth while cleft palate is about 1 per 2000 live birth. Cleft lip (with or without cleft a cleft a plate) is more common in males, while cleft palate alone is approximately twice as common in females. ${ }^{4}$ The occurrence of a cleft deformity is a source of considerable shock to the parents of an afflicted baby, and the most appropriate approach 
to the parents is to informed that the defect are correctable and need not adversely affect the child's future. ${ }^{2}$

Treatment of cleft lip and palate are very comprehensive which addresses patient's appearance, speech, hearing, mastication and swallowing. In order to treat these patients, craniofacial team is accountable. The members of this team are commonly comprise a general or pediatric dentist, an orthodontist, a prosthodontist, an oral and maxillofaciaoral surgeon or a plastic surgeon, an audiologist, an otolaryngologist, a pediatrician, a pediatrician, a speech pathologist, a psychologist or psychiatrist and a social worker. ${ }^{2}$

Cleft patient are monitored by craniofacial team through young adulthood and the treatment care can be lifelong. These treatment plan varies between patients depend on their cleft deformities. Since the incidence of cleft lip is more frequent in live birth, writer is interested to do study about the treatment for cleft lip patient particularly surgical repair of lip which is labioplasty.

The first reported case of successful closure of cleft lip at approximately 390 A.D. was made by unknown doctor in China during the Chin Dynasty5. Later, Jehan Yperman (1295-1351) a Flemish surgeon who appears to have written the first fully documented of cleft lips and its surgical repair. This technique had inspired Ambroise Pare' (1560-1590) a French surgeon to do lip repair then later, he realize that more definitive procedure are needed. In 1843, Joseph Malgaigne (1806-1865) had utilized pedicled flaps elevated bilaterally in achieving more esthetic lip and prevention of notching. Shortly thereafter, Germanicus Mirault (1796-1879) performed a straight-line closure that was developed on variation of Malgaigne's by using only one flap instead of two. Then, Le Mesurier developed procedure utilized a quadrilateral modified flap from the technique of Hagedorn. In year 1951, Charles Tennison presented "The Repair of The Unilateral Cleft Lip by Stencil Method". From this period forward, most of today's surgical procedures have evolved through modifications of previous methodology. Four years later, D. Ralph Millard develop rotation-advancement operation which overcome many of the pitfalls of earlier technique and most commonly used method for the repair of cleft lip. ${ }^{1}$

As mentioned above, craniofacial team plays the most important role in treating cleft patient. In this study, Indonesian Cleft Center Team is the selected craniofacial team which has professional oral surgeons as its listed members. This team will treat and assess the post-surgery result of cleft patient who are under Indonesian Cleft Center's management.

Indonesian Cleft Center Team is a unit of Indonesian Cleft Center (ICC) also known as Yayasan Pembina Penderita Celah Bibir dan Langitlangit Bandung (YPPCBL) was established in 1979 is a non-profit social organization that aims to provide services for cleft lip and palate patients with economic disadvantages. In carrying out its social missions, it attempts to help cleft lip and palate patients all over Indonesia. ${ }^{6}$

Indonesian Cleft Center's operational activities are medical activities including surgeries and management of cleft lip and cleft palate patients. Management of these patients includes examination, pre-operation, nursing care, and post operation nursing care. Other activities are evaluation of post operation patients by the full multi-disciplinary medical team, speech therapy, dental health services, children play group with purpose of teaching them how to recognize objects, people and the world around them and to assist these children in the development of their hearing, speech, movements, learning capabilities and behavior. ${ }^{7}$

\section{METHODS}

Type of study used is descriptive retrospective method which carried out by using patient's administrative record, post-labioplasty digital photographs and comprehensive assessment of post-surgery form (Pedoman Penilaian Hasil Pembedahan Celah Bibir dan Langit-langit) owned by cleft lip patient at Indonesian Cleft Center starting from January until December 2007.

The population of this study is patients whose are under Indonesian Cleft Center's (YPPCBL) management. The study samples were specifically patients that had undergone labioplasty and went for its assessment. In order to make the first step in this study, it requires the knowledge regarding congenital defect of cleft lip and palate specifically 
on the anatomical landmark both normal and its abnormal. Further, the comprehensive assessment of post-labioplasty form (Pedoman Penilaian Hasil Pembedahan (BL) is being studied.

Study at Indonesian Cleft Center- Faculty of Dentistry, Padjadjaran University during the Period of January Until December 2007). Data are collected and proper identification of picture and patient's evaluation are made. From the evaluation that had been made by Indonesian Cleft Center Team, all variables are being evaluated as good $(+)$, moderate $( \pm)$, poor $(-)$ and very poor (--).

\section{RESULTS}

This research was done at Indonesian Cleft Center located at Jalan Sekeloa Selatan, Bandung Indonesia. It was carried out by using the patient's administrative record during the year 2007 and 2008, post-labioplasty digital photographs and comprehensive assessment of post-surgery form (Pedoman Penilaian Hasil Pembedahan Celah Bibir dan Langit-langit) owned by cleft lip patients at Indonesian Cleft Center.

In order to explicate the result of labioplasty unbiasedly, patients were put into groups according to their clinical diagnosis. These were further divided by the original defect into incomplete and complete varieties. The groups are unilateral Incomplete Cleft Lip Patient, unilateral Complete Cleft Lip Patient, bilateral Incomplete Cleft Lip Patient, and bilateral Complete Cleft Lip Patient

Throughout the period of January until December 2007, a total number of 190 patients that came for the Comprehensive Assessment, out of the overall number 120 are post-labioplasty patient. The breakdown of the post-labioplasty patient showed that there are 35 unilateral incomplete cleft lip patients, 53 unilateral complete cleft lip patients, 5 bilateral incomplete cleft lip patients, 25 bilateral complete cleft lip patients and 2 secondary reconstructive surgeries. The remaining numbers are 70 post-palatoplasty patients. The amount of patients that came for the assessment is listed entirely in Table 1.

Further, the data are assembled and being carefully examined and organized into tables and diagrams. The results are as follows:

Performance of Labioplasty Based on Comprehensive Assessment. The performance of labioplasty for Unilateral Incomplete Cleft Lip Patients throughout the period are; 11 patients with excellent categories (31.43\%); 10 patients with good categories $(28.57 \%) ; 14$ patients with moderate categories $(40.00 \%)$; and none of these patient are categorized into poor and very poor categories $(0.00 \%)$. This data is precisely shown in Graphic 1.

The performance of labioplasty for Unilateral Complete Cleft Lip Patients throughout the period are; 9 patients with excellent categories (16.98\%); 20 patients with good categories (37.74\%); 18 patients with moderate categories (33.96\%); 5 patients with poor categories $(9.43 \%)$ and 2 patients with very poor categories (1.89\%). This data is precisely shown in Graphic 2. e performance of labioplasty for Bilateral Incomplete Cleft Lip Patients throughout the period are; 2 patients with good categories (40.00\%); 3 patients with moderate categories (60.00\%); and none of these patient are categorized into excellent, poor and very poor categories $(0.00 \%)$. This data is precisely shown in Graphic 3 .

The performance of labioplasty for Bilateral Complete Cleft Lip Patients throughout the period are; 11 patients with excellent categories (44.00\%); 7 patients with good categories (28.00\%); 5 patients with moderate categories $(20.00 \%) ; 2$ patients with poor categories $(8.00 \%)$ and none of these patients are categorized into very poor category $(0.00 \%)$. This data is precisely shown in Graphic 4.

Ranking of the least to the most complicated structure to be reconstructed in labioplasty are attained from the total numbers of each variables. Frequently evaluated with high scores variable will obtain most numbers in total value thus judged as least complicated structure to be reconstructed. In reverse, variable frequently evaluated with low scores will obtain most numbers in total value thus judged as most complicated structure to be reconstructed in labioplasty. Details in data calculation are precisely shown in Appendix 3.

There are total 35 patients in Unilateral Incommplete Cleft Lip Group. The ranking of least complicated structure to be reconstructed are; thickness of vermilion with total 120 marks followed tied by mucocutaeneous junction and symmetrical portion of lips both with 114 marks. Next, are the avoidance to leave cicatrix with 113 mark, followed by avoidance to create colobom 
Table 1. The Amount of Patients That Came for Comprehensive Assessment

\begin{tabular}{cccccccc}
\hline \multirow{2}{*}{ Months } & Number of Patients & Palatoplasty & \multicolumn{5}{c}{ Labioplasty } \\
& & & UIC UC BC BIC Second- \\
ary
\end{tabular}

Table 2 Ranking form Least to Most Complicated Structure to be Reconstructedfor Unilateral Incomplete Cleft Lip Patients

\begin{tabular}{cc}
\hline Ranking & Labioplasty structure \\
\hline 1 & Thickness of vermillion \\
$2 \mathrm{a}$ & Mucocutaneous junction \\
$2 \mathrm{~b}$ & Symmetrical portion of lips \\
3 & Cicatrix \\
4 & Colobom \\
5 & Cupid's bow \\
\hline
\end{tabular}

Table 3. Ranking form Least to Most Complicated Structure to be Reconstructedfor Unilateral Complete Cleft Lip Patients

\begin{tabular}{cc}
\hline Ranking & Labioplasty structure \\
\hline 1 & Cicatrix \\
2 & Thickness of vermillion border \\
3 & Colobom \\
4 & Mucocutaneous junction \\
5 & Symmetrical portion of lips \\
6 & Cupid's bow \\
\hline
\end{tabular}

Table 4. Ranking form Least to Most Complicated Structure to be Reconstructed for Bilateral Incomplete Cleft Lip Patient

\begin{tabular}{cc}
\hline Ranking & Labioplasty structure \\
\hline 1 & Colobom \\
2 & Cicatrix \\
4 & Mucocutaneous junction \\
5 & Symmetrical portion of lips \\
6 & Thickness of vermillion border \\
\hline
\end{tabular}


Table 5. Ranking form Least to Most Complicated Structure to Be Constructedfor Bilateral Complete Cleft Lip Patients

\begin{tabular}{cc}
\hline Ranking & Labioplasty structure \\
\hline $1 \mathrm{a}$ & Symmetrical portion of lips \\
1b & Thickness of vermillion \\
2 & Cicatrix \\
3 & Mucocutaneous junction \\
4 & Cupid's bow \\
5 & Colobom \\
\hline
\end{tabular}

Table 6 Amount of Patient Indicated for Reconstructive Surgery

\begin{tabular}{cc}
\hline Type of secondary reconstruction repair & Total number \\
\hline Secondary lip repair & 17 \\
Rhinoplasty & 6 \\
Fistula closure & 1 \\
Bone graft & 1 \\
\hline
\end{tabular}

Graphic 1. Performance Result of Labioplasty for Unilateral Incomplete

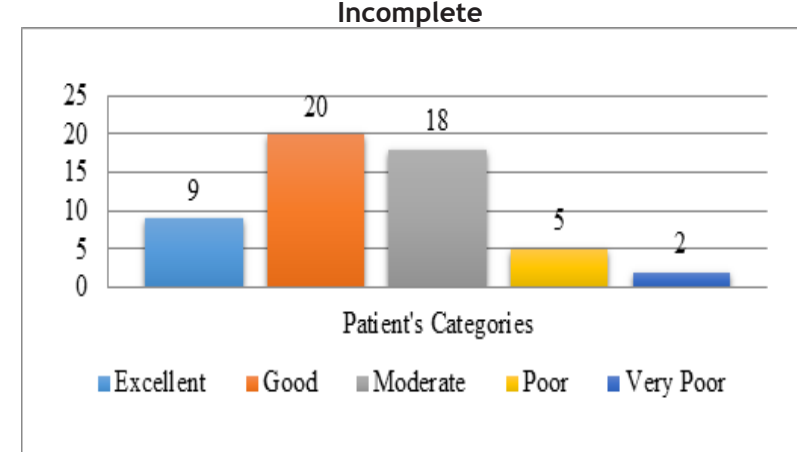

Graphic 2. Performance Result of Labioplasty for Unilateral Complete Cleft Lip Patient throughout the Period of Year 2007

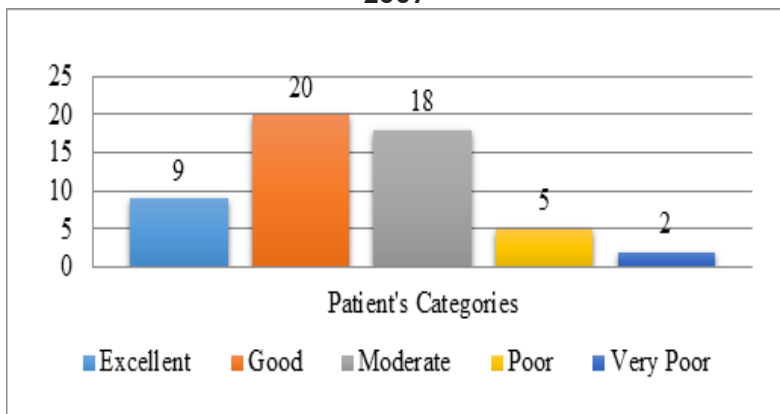

Graphic 3. Performance Result of Labioplasty for Bilateral Icomplete Cleft Lip Patient Throughout The Period of Year 2007

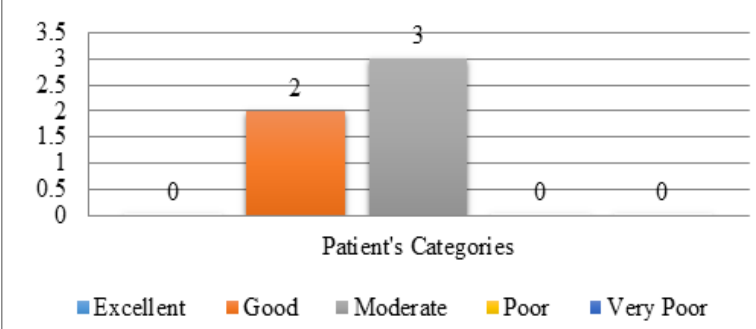

Graphic 4 Performance Result of Labioplasty for Bilateral Complete Cleft Lip Patient throughout the Period of Year 2007

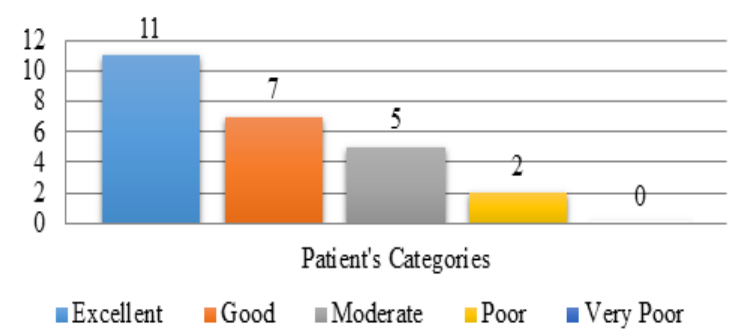

scoring 106 mark and the most complicated structure are Cupid's bow with 104 mark. Results of the ranking are recorded in Table 2 .

In Unilateral Complete Cleft Lip Patients group there are 53 patients in total that came for the evaluation. The ranking of least complicated structure to be reconstructed for this group of patients are; the avoidance to leave cicatrix with score 169 , followed by thickness of vermilion with 161 mark. The avoidance to create colobom comes in ranking number 3 with score 154 followed by mucocutaeneous junction with score 152 . Number 5 in ranking is the symmetrical portion of lips with 142 score and the most complicated structure are Cupid's bow with lowest mark, 139. Results of the ranking are recorded in Table 3:

In total, there are 5 patients in Bilateral Incomplete Cleft Lip Group. The ranking of least complicated structure to be reconstructed are; the avoidance to create Colobom with highest 17 marks, followed by the avoidance to leave cicatrix with 16 marks. Number 3 in ranking is mucocutaeneous junction with 15 marks, symmetrical portion of lips with 14 marks, thickness of vermilion with 13 marks and the most complicated structure are Cupid's bow with lowest scoring, with 12 marks. Results of the ranking are recorded in Table 4.

There are remarkable 25 patients in Bilateral Complete Cleft Lip Group. Regarding the ranking of least complicated structure to be reconstructed are lead by symmetrical portion of lips and thickness of vermilion both with 86 marks followed by avoidance to leave cicatrix with 84 marks. Mucocutaeneous junction come in number 3 in the ranking with score 82 followed by Cupid's bow with 76 marks. The most complicated structure is the avoidance to create Colobom with lowest, 
70 marks. Results of the ranking are recorded in Table 5. Types of Reconstructive Surgery Indicated for Patients to Repair Remaining Deformities. After thorough examination of the Coprehensive Assessment of Post-surgery Form (Pedoman Penilaian Hasil Pembedahan Celah Bibir dan Langit-langit), types of secondary reconstructive surgery recommended are determined at recommendation section. Types of reconstructive surgery indicated for cleft lip and cleft palate patients are secondary lip repair, rhinoplasty, fistula closure, and bone graft. Amount of Patient Indicated for Reconstructive Surgery and Amount of Patient Implemented the Surgery

Based from the Comprehensive Assessment of Post-surgery Form (Pedoman Penilaian Hasil Pembedahan Celah Bibir dan Langit-langit), amount of patient indicated and type for their reconstructive surgery are determined. Generally, post-labioplasty patient that score low marks and categorized into poor and very poor categories is indicated for the secondary lip repair. On the other hand, post-labioplasty patient that scored average marks with striking defect (in this case one of their variable are scored 1: very poor) are also indicated for this surgery. Amount of patient that is indicated for secondary lip repair are 17 patients, rhinoplasty with 6 patients, bone graft and fistula closure respectively 1 patient. The results are listed precisely in Table 6.

As soon as opportunity is open, patient is fit and eligible, indicated, surgery will be done. Based from patient's administrative 2007 and 2008 record, amount of patient that had implemented secondary reconstructive surgery are determined. Out of 25 total amounts of patients indicated, one that really implements their surgery recorded in administrative data is only one patient stated as M. Salman Fauzi with clinical diagnosis of Unilateral Cleft Lip undergoes labioplasty on 2nd February 2008.

\section{DISCUSSION}

Performance of Labioplasty Based on Comprehensive Assessment Based on this retrospective study conducted, it was record that out of a total number of 35 patients in Unilateral Incomplete Cleft Lip Group, there are 11 categorized in very good category, 10 patients in good and 14 moderate category. None of these patients were in poor and very poor categories. This is quite normal to expect because, the Unilateral Incomplete Cleft lip repair is considered as the least complicated labioplasty. It requires only slight intervention in repairing process. Minimal primary tissues deficiency is the reason why this group of patients was set as the most excellent performance compare to other groups.

In Unilateral Complete Cleft Lip Patients, the performance are rather jumbled up with 9 patients with excellent categories, 20 patients with good categories, 18 patients with moderate categories, 5 and 2 patients with poor and very poor categories respectively. Comparisons of performance of labioplasty are between Unilateral Incomplete Cleft Lip and Unilateral Complete Cleft Lip made in form of percentile. There are $31.43 \%$ of Unilateral Incomplete Cleft Lip and $16.98 \%$ of Unilateral Complete Cleft Lip patients categorized in excellent category. This number is quite normal to be expected with the reasons that Unilateral Incomplete Cleft Lip is the simplest defect compare to other cases.

In good category, there are lower percentage in Unilateral Incomplete Cleft Lip group compare to Unilateral Complete group with $28.7 \%$ and $37.7 \%$ respectively. It shows that the performance result of labioplasty does not necessarily coincide with the severity of the cases. In contrary, according to study conducted by Montier et al. (1997) proved how the postoperative result scores in the most serious clefts were significantly worse than those of the least serious cleft. This unexpected pattern might be occurred due to surgeons had underestimated the Unilateral Incomplete Cleft Lip cases and assuming that this type of deformity does not require meticulous considerations. The other reasons are because the surgeons that incharge are highly experience and proficiency skilled and able to handle this case outstandingly[8]. Adding to that, the Unilateral Complete Cleft Lip cases are not too extreme which later, produce a better result.

In moderate category, both in Unilateral Incomplete Cleft Lip and Unilateral Complete Cleft Lip scores highest percentage of all compare other categories with both $40 \%$ and $33.9 \%$ respectively. This is might be because normally majority of surgeons can at least perform moderate level of 
end result. There are no Unilateral Incomplete Cleft Lip patient categorized in poor and very poor category where as there are total $9.43 \%$ in poor and $1.89 \%$ in very poor category in Unilateral Complete Cleft Lip. Based on observation of photographic picture of these patients, there is great severity of the cleft and severely rotated maxillary segments.

Comparisons of performance of labioplasty are between Bilateral Incomplete Cleft Lip and Bilateral Complete Cleft Lip is made roughly due to huge differences of total number of patients. Approximately, the result that Bilateral Incomplete Cleft Lip are more superior compare to Bilateral Complete Cleft Lip are normal to be expected due to the severity of the cleft and primary tissue deficiency.

Comparatively, repairs of the bilateral cleft lip far have been less successful in accomplishing a normal-looking lip than have unilateral repairs (Booth, et. al., 2007). It is often quoted that compared with the unilateral cleft 'the bilateral cleft is twice as difficult, and the result are half as good'9]. According to one of the surgeon incharge here at Indonesian Cleft Center- Faculty of Dentistry Padjadjaran University, labioplasty in bilateral cleft lip is far more complicated compare to unilateral cleft lip. This is because; in bilateral cleft lip there is no normal side or non-cleft side to referred as criterion10. Mortier and colleague (1997) had take into account the difficulty in correcting residual defects by following tissue loss are usually more difficult to correct than defect without tissue loss.

With astounding years of experience, Indonesian Cleft Center Team is expected able to handle every case judiciously regarding its clinical severity. Thus, team's performances are expected to be good in each case. There are numerous factors influencing the results of labioplasty. Author concludes that there are four main classifications of factors influencing the result according to time line and it may overlap on each other depending on the situations. First, it was during pre-operation; during the operation; postoperation and lastly, during the evaluation itself.

Pre-operative considerations include the clinical examination, treatment plan and timing. Examination on the lip should focus on the type, extent, width of the cleft, vermillion and degree of upward curvature of both lip segment. ${ }^{11}$ Besides that, the degree of hypoplasia of the tissue and the bony structures; the position of maxillary segments; and the type of degree of nasal deformity. ${ }^{12}$ also should be observed. Preoperative evaluation is also important for choosing the surgical technique most appropriate to the particular type of cleft. Mistake in preoperative assessment may result from lack of experience and inattention to details. ${ }^{11}$

Other variations in complexity are the timing of labioplasty13. Cleft lip repair must be performed when the child is in good health (Bardach and Salyer, 2000). "The rule of 10" as proposed William and Musgarve as previously discussed in Chapter II serve as cardinal rule in determining the timing of labioplasty surgery. At present, most surgeons follow "The rule of 10"12. Here, at Indonesian Cleft Center, timing of labioplasty are depend on the patient's awareness and timing when patient's first came to Indonesian Cleft Center to seek for treatment. Patient's age are approximately varies from 3 months old until 23 years old. It is stated that, some surgeons operate very early sometimes as early as the first weeks of life, but have no presented a rationale for their choice of timing. ${ }^{12}$

Factors influencing the result of labioplasty during the operation include the experience and proficiency of the surgeon, the surgical technique used12, causative effect of tissue distortion during the surgery and condition of lip during measurement. Another common intraopertive error are poor surgical technique and lip repair performed under excessive tension. ${ }^{11}$ Experience and proficiency of a surgeon are usually determined by the length of 'operation flying hours' they had gained. Surgeons here that in-charge are highly experience and proficiency skilled. In the case that labioplasty conducted by inexperience surgeon, the surgery are observed by these consultants thus the end result of labioplasty would be the same.

In operative room, preoperative errors of judgment may cause by distortion of lip due to incorrect placement or taping of the endotracheal tube. Even though the tube may be perfectly placed and well taped, distortion occurs when measurements are made with the mouth wide open. ${ }^{11}$ Instead, measurement should be made when the lips are totally relaxed and almost close. 
In order to get correct measurement the surgeon in-charge here should ensure proper placement of endotracheal tube and measuring are made while lips are relaxed.

Another cause of tissue distortion is related to local anesthesia. ${ }^{11}$ Local anesthesia or adrenaline is used to enlarge dimensions and serves as vasoconstriction to prevent bleeding of the superior labial artery. ${ }^{14}$ This creates a situation in which measurement, design, and tissue adjustment may not be precise enough. ${ }^{11}$ To overcome this detrimental effect, surgeon incharge here will draw the pattern of incision and tattooed the landmark by using methyl blue ink before injecting local anesthesia. ${ }^{15}$

Poor surgical technique is attributable not only to inadequate design but also to rough tissue handling and improper adjustment of the various part of the cleft lip. Another source of failure is lip repair performed under excessive tension. This condition would normally occur in patient with wide, especially when the rotation-advancement technique is used and when too much tissue had been sacrificed at the time of lip repair. ${ }^{11}$ Excessive tension will cause taut of the upper lip, causing pouting of the lower lip. The concept of excessive tension is reduced by wide undermining of tissue on both side of face of the maxilla. ${ }^{11}$

Factors influencing the result of labioplasty soon after the surgery are the postoperative course, which is, healing complication, scar contracture. ${ }^{16}$ and effect of growth on a particular surgical technique.

As mentioned before, surgical technique used influence the result of labioplasty. Here, in Indonesian Cleft Center, two surgical techniques are used in repairing unilateral cleft lip which is the Tennison and Millard techniques. On the other hand, surgical techniques used in repairing bilateral cleft lip deformity are the Veau III and Noordhoff techniques.

On growth aspect, an occasional problem with cleft lip repairs is a discrepancy in vertical height of the lip as measured from nose to the vermillion. Le Mesurier, Asensio and occasionally Tennison techniques result in too long a lip on repaired side. Conversely, the Millard repair may result in too short a lip. ${ }^{17}$ Here at Indonesian Cleft Center, the surgeons are using Tennison-Randall's technique to overcome the detrimental lengthening effect. The other factors influence the post-labioplasty results are healing complications and scar contracture. ${ }^{12}$ Improper and inadequate proper wound management will impaired the process of wound healing and leads to complications such as formation of pus, wound dehiscence and potential hypertrophic scar.

This will form excessive formation of cicatrix and worse, causing scar contracture. ${ }^{12}$ All of post-labioplasty patients treated at Oral and Maxillofacial Department of Rumah Sakit Dr Hasan Sadikin are under observation for seven days. On each day, surgical wound are cleaned properly, application of new dressing with topical antibiotics and medication that promotes wound healing. Drug of choice that frequently used in Rumah Sakit Dr Hasan Sadikin is Oxoferin. It is a topical wound healing agent that has a positive impact on wound healing leading to closure and faster healing of wounds. ${ }^{18}$

Scars are usually termed hypertrophic when they developed excessive redness, elevation, widening and stiffness. Carefully designed incision lines, anatomically appropriate muscle reconstruction and atraumatic suturing are essential for optimal scars. ${ }^{19}$ However, because of continuous muscle contraction and skin tension caused by infant crying and feeding, it is very difficult to achieve a satisfactory effect after lip repair. The surrounding tissue is compressed because of muscle contraction and will increase the skin tension leads to formation of scar contracture. It is suggested that usage of lip bumper will protect the wound and administration of Botulinum Toxin to paralyse the lip muscles. Both, will create a good condition for wound healing and reduction of the formation of lip scar after lip repair. ${ }^{19}$

Factors influencing the result of labioplasty during the evaluation itself are method of assessment made and intra- and inter-examiner perception of labioplasty result. The method described for assessment can be broadly divided into qualitative and quantitative. The latter aim to analyze objectively the extent of abnormal morphology and the degree of disproportion trough facial measurements. ${ }^{20}$ This approach neglects the fact that the harmony of a person's face is more than the sum of the contributing parts[21]. Qualitative methods are more subjective 
and analyze facial aesthetic and appearance impairment using scoring systems and rankings. Subjective assessment of appearance and aesthetic is fraught with difficulties, but is most likely reflected the patient's and general public's perception of facial impairment. ${ }^{21}$ The qualitative assessment of the nasolabial appearance has been used as a reliable system of evaluation of the surgical outcomes. ${ }^{22}$

Post-surgery Assessment Form (Pedoman Penilaian Hasil Pembedahan Celah Bibir dan Langit-langit) is assessing the restoration of anatomical structure without assessing functional restoration of the lip. This form was used in this study by means are a qualitative method in assessing the labioplasty result. However, in order to introduce an element of objectivity into an essentially subjective decision, criteria were devised for assessment of each view based upon the characteristic stigmata of repaired cleft. ${ }^{21}$

Recently, Al-Omari et al., (2005) published a literature search conducted to identify all publications that assessed the cleft-realted deformity both qualitatively and quantitatively, they found 40 publication that were categorized according to stimulus media utilized for the assessment in: clinical assessment; twodimensional media by using photographs; threedimensional media by using laser scanning, computer-aided tomography; and comparing clinical assessment with that from two or threedimensional. Here, in this study, two-dimensional media by observing post-labioplasty photograph had been conducted. ${ }^{23}$ There are limitations of still photography, but using moving images or complex computerized system would raise the level of complexity and the burden, without solving the real obstacles in the clinical research of cleft lip and palate treatment. ${ }^{24}$ Advantages of photography as media are its validity, reproductibility, relevancy and more patient-oriented, with no burden and easier storage and management. ${ }^{24}$

Addition to the factors influencing the result of labioplasty is intra- and inter-examiner perception of labioplasty's result. Examiner exhibited differences in the ratings of individual subject. Similar concerns extend to the subjective assessment of lip form and function in patients with cleft lip and palate. ${ }^{25}$ Professional examiner gave ratings of greater severity and impairment than layperson does. ${ }^{25}$ Since there are details clarification system written in Post-surgery Evaluation Form (Pedoman Penilaian Hasil Pembedahan Celah Bibir dan Langit-langit), this factor hopefully, diminished from influencing the result of labioplasty.

The real factor that influenced the accumulation of evidence based knowledge about cleft lip and palate treatment are he real researcher's motivations, sample selection, problems related to population heterogeneity, impatience, samples of twenty or thirty, lack of statistical forethought, holding variables constant, definitions of success and interpretation of results. ${ }^{26}$

In this study, evaluations are made approximately one month subsequent to the labioplasty. Growth of repaired cleft lip has influence the result of labioplasty. Exactly right after the surgery, ones can scrutinize the endresult of labioplasty that was beautifully done by the surgeon. But, the end-result of labioplasty will be differ if the observation are made in the next one month, next one year or two years especially the patient had reached adulthood. However, should bear in mind that objective of labioplasty which are normal criteria of repaired cleft lip should not be distorted by the effect of lip growth and aging. ${ }^{5}$

Least to Most Complicated Structure to be Reconstructed in Labioplasty. Based on the trend ranking of the least to the most complicated structure to be reconstructed in labioplasty can conclude. Structure that frequently listed as least complicated structures are the thickness of vermilion and avoidance to create cicatrix. While structure that frequently listed as most complicated structure to be reconstructed is definitely Cupid's bow. According to Bardach and Noordhoff (1997), secondary deformities of the vermilion and the Cupid's bow are the most common deformities seen after cleft lip repair. ${ }^{11}$

On the other hand, there are some unexpected results seen. Avoidance to create cicatrix in Unilateral Incomplete Cleft Lip cases are in the fourth ranking. As mentioned before, Unilateral Incomplete Cleft Lip is the least complicated labioplasty and requires slight intervention thus, the formation of cicatrix are supposed to be avoidable. In Bilateral Complete 
Cleft Lip, symmetrical portion of the lip were in the first ranking showing that it is the least complicated structure to be reconstructed whilst it was in fourth ranking in Bilateral Complete Cleft Lip cases. It was stated by Florence (2009), that in bilateral cleft lip there is no normal side or noncleft side to refer as criterion thus achieving the symmetric lip is almost difficult to achieve. ${ }^{10}$

Types of Secondary Reconstructive Surgery Indicated for Patients to Repair Remaining Deformities. Types of secondary reconstructive surgery indicated for patients to repair remaining deformities are obtained from the Comprehensive Assessment of Post-Labioplasty Form (Pedoman Penilaian Hasil Pembedahan Celah Bibir dan Langit-langit) at the recommendation section. Types of reconstructive surgery indicated for cleft lip and cleft palate patients are secondary lip repair, rhinoplasty, fistula closure and bone graft. Correction of secondary deformities is complex because there are usually other deformities which must be corrected and which often incorporated into the same surgical procedure. Careful analysis of all existing problems is needed to determine the sequence of the surgical procedure so that maximal improvement is achieved in one operation. ${ }^{11}$

Amount of Patient Indicated for Secondary Reconstructive Surgery and Amount of Patient Implemented the Surgery. The amount of patient that is indicated for secondary lip repair are 17 patients, rhinoplasty with 6 patients, bone graft and fistula closure respectively 1 patient. According to the topic of this research, only amount of 17 cleft lip patients are going to be discussed here. As mention above, post-labioplasty in poor and very poor categories (in total is 8 patients) and patient with striking subunit anatomical structure (in total is 9 patients) defect are indicated. Total amount of patient that really implement their surgery are 1 patient.

Factors that explain these numbers are because the patients are satisfied with their current appearance. Any distortions have an important influence on facial attractiveness, which may in turn have psychosocial implications. The psychosocial parameters of importance in cleft lip and palate care are not clearly established (Morris and Bardach, 1989), but they include peer acceptance, social competence, educational achievement, self-esteem and satisfaction. It is widely accepted that facial appearance is important in forming first impression, and acts as a cue for social stereotyping. ${ }^{14}$ However, the relationship between psychosocial adjustment and facial morphology is complex and still not well understood; although some evidence suggest that a greater physical disfigurement is associated with greater internalizing behavior. ${ }^{27}$

Besides, patient's parents did not give consent because their judgmental thinking that their children (post-labioplasty patient) will suffer more results from the surgical trauma. Occasionally, socio-geographical is the factor preventing patients to received secondary surgery because they had difficulties to travel to Indonesian Cleft Center at Bandung. However, one must consider the important of labioplasty outcomes from the patient's and family's perspective rather than the professionals. ${ }^{28}$

\section{CONCLUSION}

The performance result of labioplasty according to the comprehensive assessment performed by Indonesian Cleft Center Team during the period of January till December 2007 does not necessarily coincided with the severity of the cases, the most complicated structure to be reconstructed in labioplasty is Cupid's bow whilst among the least complicated structure to be reconstructed are the thickness of vermilion and avoidance to create cicatrix, type of secondary reconstructive indicated for the patient to repair the remaining deformities are secondary lip repair, rhinoplasty, fistula closure and bone graft, and the amount of patient that is indicated for secondary reconstructive surgery is total 25 patients. The breakdown number are 17 patients indicated for secondary lip repair, 6 patients indicated for rhinoplasty, bone graft and fistula closure respectively 1 patient. Amount of patient that really implement their surgery are only 1 patient.

\section{REFERENCES}

1. Malek R. Cleft Lip and Plalate Lesions, Pathophysiology and Primary Treatment. London; Martin Dunitz Ltd. 2001;31-36, 39 $102 \mathrm{pp}$. 
2. Peterson L, Ellis J, Hupp E, Tucker JR. Contemporary Oral and Maxillofacial Surgery. India;Mosby. 2003. 632 pp.

3. Berkovitz BKB, Holland GR, Moxham BJ. Oral Anatomy, Embryology and Histology. Edinburgh; Mosby. 2002. 272pp.

4. Cawson RA, Odell EW, Porter S. Cawson's Essential of Oral Pathology and Oral Medicine. Edinburgh; Mosby. 2002. 32 pp.

5. Converse JM, Hogan VM, MCCarthy JG. Reconstructive Plastic Surgery. Volume Four Cleft Lip and Palate Craniofacial Deformities. Philadelphia, London, Toronto; W.B. Saunders Company.1977. 1930 pp.

6. YPPCBL: Indonesian Cleft Center YPPCBL Profile \& Activity" Avaiable at: http:// indonesiancleftcenter.org/index. php?lang=en\&page=home (retrieved on 23 July 2009)

7. Evy R. Helping Children With Cleft Lip and Palate in Indonesia. Available online at: http://senyumsehat.wordpress.com/shareyour-smile/ retrieved on 23 Febuary 2009

8. Mortier PB, Martinot VL, Anastassov Y, Kulik JF, Duhamel A, Pellerin PN. Evaluation of the Result of Cleft Lip and Palate Surgical Treatment: Preliminary report. J Cleft PalateCraniofacial. 1997;34(4):247-255.

9. Elhidady M, Eldeen AM, Elbassiouny L. An Improved Technique for Repair of Bilaterla Cleft Lip Dedormities through Extensive Musscle Dissection in One Stage Surgery. Egypt, J. Plast. Reconstr. Surg. 2006;30(2): 131-137.

10. Florence M. Teknik Noordhoff pada Celah Bibir Bilateral, Fakultas Kedokteran Gigi Universitas Padjadjaran. 2009.

11. Bardach J., Noordhoff M.S, 1997; Correction of Secondary Unilateral Cleft Lip Deformities; Surgical Technique in Cleft Lip and Palate. 58$63 \mathrm{pp}$

12. Bardach J, Slayer K. Unilateral Cleft Lip Repair; Surgical Technique in Cleft Lip and Palate. 2000. 1-3 pp.

13. Hudson JW. Oral and Maxillofacial Surgery Clinics of North America. Philadelphia; W.B. Saunders Company. 1991. 531 pp

14. Shoroghi M, Sadrolsadat SH, Razzaghi M, Farahbakhsh F, Sheikhvatan M, Sheikhfathollahi M, Abbasi A. Effect of different epinephrine concentrations on local bleeding and hemodynamics during dermatologic surgery. Acta Dermatovenerol Croat. 2008;16(4):20914.

15. Soesanto R. Pengukuran Ketebalan Bibir Merah Kasus Celah Bibir Satu Sisi pada Teknink Pembedahan Tennison. 1998. 2 pp

16. Bardach J, Morris H. Multidisciplinary Management of Cleft Lip and Palate Philadelphia, London, Toronto, Montreal, Sydney. Tokyo: W.B. Saunders Company. 1990. 134 pp.

17. Kaplan EN. Growth of The Unilateral Cleft Lip. Cleft Palate Journal. 1978;(15)3:202-205.

18. Chaplin DD. Overview of the Immune Response. J Allergy Clin Immunol. 2010 Feb; 125(2 Suppl 2): S3-23.

19. Liu RK, Li CH, Zou SJ. Reducing Scar Formation After Lip Repair by Injecting Botulinum Toxin. J. plastic and Reconstructive Surgery. 2010;125(5):1573-74.

20. Renna MD, Pisani P, Conversano F, Perrone E, Casciaro E, Renzo GCD, Paola MD. et al. Sonographic markers for early diagnosis of fetal malformations. World J Radiol. 2013 Oct 28;5(10):356-371. DOI: 10.4329/wjr. v5.i10.356

21. Bermudez L. Photography as Media for Assessment of Cleft Deformity and Surgical Outcomes. 25th Operation Smile. 2007. 1-4pp.

22. Al-Omari I, Millett DT, Ayoub AF. Methods of assessment of cleft-related facial deformity: a review. Cleft Palate Craniofac J. 2005 Mar;42(2):145-56. DOI: 10.1597/02-149.1

23. Bermudez L, Magee W., Weatherley-White C, Rubin R. Nasolabial Evalaution of the Bilateral Cleft Lip Repair. 25th Operation Smile. 2007. 1-27pp.

24. Ritter K, Trotman C, Phillps C. Validity of Subjective Evaluations for the Assessement of Lip Scarring and Impairment. J Cleft PalateCraniofacial. 2009;39(6):587-596 pp.

25. Shprintzen RJ. Fallibility of Clinical Research. J. Cleft Palate Craniofac. 1991;28(1)136-140.

26. Zeraatkar M, Ajami S, Nadjmi N, Faghihi SA, Golkari A. A qualitative study of children's quality of life in the context of living with cleft lip and palate. Pediatric Health Med Ther. 2019;10:13-20. doi: 10.2147/PHMT.S173070 
27. Penfold CN, Schendel SA. Cleft Lip and Palate Evidence-Based Care.China. Churchill Livingstone. 2007.

28. Cook RJ, Dicknes BM, Fathalla MF. Female genital cutting (mutilation/circumcision): Ethical and legal dimensions. Int J Gyneco \& Obste. 2003;79(3):281-7. DOI: 10.1016/S00207292(02)00277-1 